\title{
SUXAMETHONIUM-INDUCED JAW STIFFNESS AND MYALGIA ASSOCIATED WITH ATYPICAL CHOLINESTERASE: CASE REPORT
}

\author{
R. Melvoll, J. Stovner and M. Whittaker
}

\begin{abstract}
An 11-year-old boy was given halothane, nitrous oxide and oxygen, pancuronium $0.4 \mathrm{mg}$ and suxamethonium $100 \mathrm{mg}$ for induction of anaesthesia. In response to this a marked jaw stiffness occurred which lasted for two minutes and the anaesthesia was terminated. Four hours of apnoea ensued and he suffered generalized severe myalgia lasting for one week. He was found to have atypical plasma cholinesterase with a dibucaine number of 12 , indicating homozygocity. This was verified by study of the family.

The case shows that prolonged jaw rigidity and myalgia may occur after suxamethonium in patients with atypical cholinesterase despite pretreatment with pancuronium.
\end{abstract}

THE PLASMA CHOLINESTERASE VARIANT which is resistant to dibucaine inhibition has been known for more than 20 years. "When the patient is homozygous for the enzyme defect he always shows prolonged apnoea after suxamethonium because the drug is hardly destroyed at all in these patients.

A more recently described variant of plasma cholinesterase is the type resistant to inhibition by the fluoride ion. ${ }^{2}$ This variant has been found associated with congenital diseases such as Huntington's chorea, ${ }^{3}$ Down's syndrome ${ }^{4}$ and in three cases malignant hyperthermia. ${ }^{5}$ This is in contrast to the original dibucaine resistant type which so far has not been associated with specific diseases. Single cases, however, have occurred in a large number of different pathological conditions.

The present case combines the occurrence of a homozygote dibucaine resistant plasma cholinesterase in a patient reacting to suxamethonium with jaw stiffness lasting more than two minutes and severe myalgia lasting for one week.

\section{Case History}

An 11-year-old boy weighing $36 \mathrm{~kg}$ had sustained a leg fracture 18 days previously and was to have reposition and immobilization under general anaesthesia. He was in good general condition but had pectus excavatus. His family was healthy although his father had elevated creatine

R. Melvoll, M.D., J. Stovner, M.D., Department of Anaesthesia, University Hospitals, Oslo, Norway; M, Whittaker, The Cholinesterase Research Unit, University of Exeter, Exeter, England. phosphokinase (CPK) values in two subsequent blood samples. The patient's CPK was normal.

After premedication with atropine $0.6 \mathrm{mg}$ he was given halothane $1-2$ per cent in nitrous oxide and oxygen (50:50) for two to three minutes. He was then given pancuronium $0.4 \mathrm{mg}$ intravenously followed in two minutes by suxamethonium $50 \mathrm{mg}$. Almost immediately this produced severe spasm of the lower jaw, making intubation difficult. Another $50 \mathrm{mg}$ of suxamethonium was given but the jaw stiffness lasted for more than two minutes before it disappeared. He was then ventilated with pure oxygen because the anaesthetist feared the development of malignant hyperthermia. The fracture was quickly repositioned and immobilized in plaster without any further anaesthesia.

As the patient showed no signs of spontaneous breathing or cough when tracheal suction was applied, he was ventilated mechanically with nitrous oxide and oxygen (50:50). An arterial blood sample revealed normal blood gases and the temperature only rose from the morning temperature of $36.9^{\circ}$ to $38^{\circ} \mathrm{C}$. After four hours on the ventilator spontaneous respiration returned and he could be extubated.

The next day the patient complained of severe pains in all the muscles of his body. Because of these pains he had to stay in bed for a week and received analgesic medication. Otherwise the recovery was uneventful.

Blood samples from the boy and his family revealed the enzyme pattern shown in Figure 1 . The boy was homozygous with a dibucaine number of 12 , while the parents and a brother were heterozygous for the dibucaine resistant 


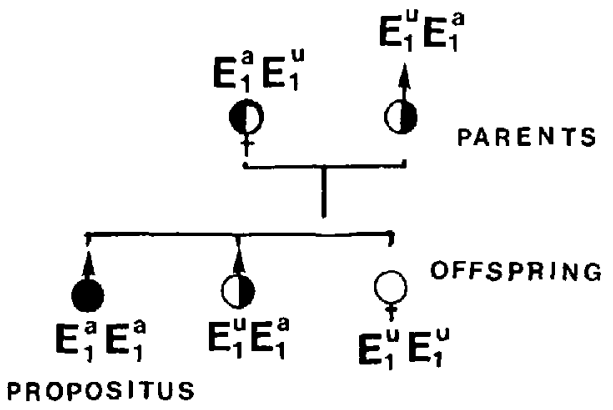

Figure I Family of propositus. Propositus had Dibucaine no. 12 and Fluoride no. 14.

gene. A sister showed the normal enzyme variant.

\section{Discussion}

In this patient we observed two sets of manifestations after suxamethonium: (1) Jaw stiffness, lasting for more than two minutes after the suxamethonium and severe myalgia lasting for a whole week. (2) Prolonged apnoea due to homozygocity for the dibucaine resistant variety of plasma cholinesterase.

Jaw stiffness lasting more than a few seconds after suxamethonium is a warning signal that malignant hyperthermia might follow and anaesthesia should therefore be terminated. ${ }^{6-8}$ In this case it was perhaps stopped by preadministration of a small dose of pancuronium. Pretreatment with nondepolarizing relaxants has been shown to prevent suxamethonium induced rise in creatine phosphokinase. ${ }^{9}$ However, tubocurarine has been claimed to induce malignant hyperthermia in at least two patients ${ }^{10}$ and pancuronium has been shown to induce malignant hyperthermia in pigs. " The present case shows that pretreatment with non-depolarizing relaxants may not prevent jaw stiffness and myalgia induced by suxamethonium.

A diagnosis of malignant hyperthermia cannot be made with certainty in this case because the temperature only rose to $38^{\circ} \mathrm{C}$, no acidosis was found and a postoperative $C P K$ of the patient was not obtained. Pectus excavatus and family members with elevated CPK values have been found in association with malignant hyperthermia, but the incidence is low. ${ }^{12}$ Although the prolonged jaw stiffness found in our case is a valuable warning signal it does not prove that our patient was a potential candidate for malignant hyperthermia. The fact that halothane was used before the injection of suxamethonium might have precipitated both the jaw stiffness and the postoperative myalgia. An indication of this is the finding that halothane increases the $C P K$ liberation by 5 to 10 times. ${ }^{13.14}$ Definite tests ${ }^{15.16}$ for malignant hyperthermia, such as caffeine contractures or serum pyrophosphate levels have not been done in this case.

Baraka originally suggested, on the basis of findings in two brothers, that patients with atypical cholinesterase react to suxamethonium with the absence of fasciculations and muscle movements. ${ }^{17}$ This was later disproved. ${ }^{18.19}$ Our patient had atypical cholinesterase and reacted with jaw stiffness and severe myalgia to halothane and suxamethonium. This occurred in spite of a dose of pancuronium given before the suxamethonium.

\section{REFERENCES}

I. Kalow, W. \& Genest, K. A Method for the detection of atypical forms of human serum cholinesterase: Determination of the dibucaine numbers. Can. J. Biochem. 35: 339 (1957).

2. Harris, H. \& WhITtAKER, M. Differential inhibition of human serum cholinesterase with fluoride. Recognition of two new phenotypes. Nature. Lond. 191: 496 (1961).

3. Whittaker, M. \& BerRy, M. The plasma cholinesterase variants in mentally ill patients. Brit. J. Psychiat. 130: 397 (1977).

4. Whittaker, M. \& Berry, M. Plasma cholinesterase polymorphism in Downs syndrome. Hum. Hered. 27: 52 (1977).

5. Whittaker. M., Spencer, R. \& Sfarle, J. Plasma cholinesterase and malignant hyperthermia. Brit. J. Anaesth. 49: 393 (1977)

6. Relton, J.E.S., Steward, D.J., Creighton, R.E. \& BRIT, B.A. Malignant hyperthermia. A therapeutic and investigative regimen. Cantad. Anaesth. Soc. J. 19:200 (1972).

7. Corballo. A.S. Aborted malignant hyperthermia. Case report. Canad. Anaesth. Soc. J. 22: 227 (1975).

8. Stovner, J., Innes, K.R. \& Holen, A. Ten cases of malignant hyperthermia in Norway. Canad. Anaesth. Soc. J. 23: 518 (1976).

9. Tammisto. T., LeikKonen, P. \& Airaksinen, M. The inhibitory effect of D-tubocurarine on the increase of serum creatine kinase activity produced by intermittent suxamethonium administration during halothane anaesthesia. Acta anaesth. Scandinav. I1: 333 (1967).

10. Britt, B.A., Webi. M.D. \& Le Duc, C. Malignant hyperthermia induced by curare. Canad. Anaesth. Soc. J. 2I: 371 (1974).

11. Chalstrey, L.J. \& Edward, G.B. Fatal hyperpyrexia following the use of pancuronium in the pig. Brit. J. Anaesth. 44: 91 (1972).

12. King, J.O., Dengorough, M.A. \& ZapF. P.W Inheritance of malignant hyperthermia. Lancet. I: 365 (1972). 
13. Tammisto, T. \& AIRAKSINEN, M. Increase of creatine phosphokinase activity in serum as a sign of muscular injury caused by intermittent administration of suxamethonium during halothane anaesthesia. Brit. J. A naesth. 38: 510 (1966).

14. INNES, R.K.P. \& STrqmmE, J.H. Rise in serum creatine phosphokinase associated with agents used in anaesthesia. Brit. J. Anaesth. 45: 185 (1973).

15. Britt, B.A., McComas, A.J., Endrenyi, L. \& KALow, W. Motor unit counting and the caffeine contracture test in malignant hyperthermia. Anaesthesiology 47: 490 (1977).

16. Kalow, W., Britt, B.A.\& Peters, P. Rapid sim- plified technique for measuring caffeine contracture for patients with malignant hyperthermia in Second International Symposium on Malignant Hyperthermia. Ed. by J.A. Aldrete, B.A. Britt. New York. Grune \& Stratton 339-350 (1978).

17. BarakA. A. Absence of suxamethonium fasciculations in patients with atypical plasma cholinesterase. Brit. J. Anaesth. 47: 419 (1975).

18. Hunter, J.M. Absence of suxamethonium fasciculations in patients with atypical plasma cholinesterase. Brit. J. Anaesth. 47: 1340 (1975).

19. Viby-Mogensen, J. Presence of suxamethonium fasciculations in patients with alypical plasma cholinesterase. Brit. J. Anaesth. 48: 1030 (1976).

\section{RÉSUMÉ}

On a administré de l'halothane, un mélange protoxyde d'azoteoxygène, du pancuronium 0.4 mg suivide suxaméthonium à un enfant de 11 ans pour l'induction de l'anesthésie. A la suite de l'administration de ces médicaments, il fut noté une rigidité importante de la mâchoire qui dura deux minutes et à la suite de laquelle la décision de terminer l'anesthésie fut prise. II s'ensuivit une apnée de quatre heures et suivie d'une myalgie sévère d'une durée d'une semaine. On détermina plus tard que le malade était porteur d'une pseudocholinestérase atypique avec un index de dibucaine à 12 , indicateur d homozygotisme, ce qui fut confirmé par une étude familiale.

Cette observation montre qu'une rigidité prolongée de la mâchoire avec myalgic peut survenir après l'administration de suxaméthonium chez les malades porteurs de pseudocholinestérase atypique même après prétraitement au pancuronium 